\title{
Studi Komparasi Kinerja Konselor dalam Layanan Konseling Individual Berdasarkan Self Evaluation dan Peer Evaluation
}

\author{
Muya Barida, Sutarno Sutarno \\ Program Studi Bimbingan dan Konseling, Fakultas Keguruan dan Ilmu Pendidikan, \\ Universitas Ahmad Dahlan, Jl. Pramuka No. 42, Yogyakarta, Daerah Istimewa Yogyakarta, Indonesia 55161 \\ E-mail:moza_barid@yahoo.com
}

Artikel diterima: 3 November 2017; direvisi 17 Februari 2018; disetujui 2 Maret 2018

\begin{abstract}
The purpose of this study was to evaluate school counselor performance in organizing individual counseling services using self evaluation and peer evaluation. This study uses descriptive survey approach through descriptive comparative study. Subjects are school counselors in Special Region of Yogyakarta, especially Bantul District. Data analysis used Mann-Whitney U test. Based on result obtained by Mann-Whitney U significance value between self evaluation with peer evaluation is $0,657(>0,05)$. This means that there is no significant difference in counselor performance evaluation based on self evaluation and peer evaluation instruments.
\end{abstract}

Keywords: self evaluation; peer evaluation; counselor performance; individual counseling

\begin{abstract}
Abstrak: Tujuan penelitian ini adalah untuk melakukan evaluasi kinerja konselor sekolah dalam menyelenggarakan layanan konseling individual melalui self evaluation dan peer evaluation. Penelitian ini menggunakan pendekatan descriptive survey melalui rancangan descriptive comparative study. Subjek adalah konselor di Daerah Istimewa Yogyakarta (DIY), khususnya Kabupaten Bantul. Teknik analisis menggunakan rumus Mann-Whitney U. Berdasarkan analisis hasil penelitian diperoleh nilai signifikansi Mann-Whitney U antara self evaluation dengan peer evaluation yaitu sebesar $0,657(>0,05)$. Artinya tidak ada perbedaan signifikan penilaian kinerja konselor berdasarkan pengisian instrumen self evaluation dan peer evaluation.
\end{abstract}

Kata kunci: self evaluation; peer evaluation; kinerja konselor; konseling individual

Bimbingan dan konseling (BK) mempunyai fungsi strategis di dalam pendidikan (Nurse, 2014). Di Indonesia, pemerintah mengakui keberadaan BK secara formal pada tahun 1975 dengan memasukkannya ke dalam kurikulum pendidikan di sekolah dengan wilayah kerja BK sebagai pihak yang memandirikan siswa. BK bertujuan untuk memandirikan siswa agar dapat mencapai potensi yang optimal dalam aspek pribadi, sosial, akademik, dan karier (ABKIN, 2007). Pihak yang berhak memberikan layanan BK di sekolah disebut sebagai guru BK atau konselor. Konselor sebagai manajer dalam layanan BK mempunyai peran dan tanggung jawab yang besar terhadap keberhasilan pencapaian tujuan siswa. Peran dan tanggung jawab tersebut, menuntut konselor untuk menunjukkan kinerja yang sesuai kompetensi akademik dan standar kompetensi profesional (Radjah, 2016).

Sebuah temuan tentang kinerja konselor pada kegiatan BK di jenjang Taman Kanak-kanak (TK); Sekolah Dasar (SD); Sekolah Menengah Pertama (SMP); dan Sekolah Menengah Atas (SMA) menunjukkan bahwa: (1) kegiatan penilaian atau pengujian yang dilaksanakan oleh konselor di TK/SD menunjukkan rata-rata kinerja sebesar 6,29\%, SMP 7,27\%, dan SMA 6,68\%; (2) kegiatan 
bimbingan di TK/SD menunjukkan rata-rata sebesar 24,19\%, SMP 13,18\%, dan SMA 11,47\%; (3) kegiatan konseling individu di TK/SD sebesar 27,31\%, SMP 28,60\%, dan SMA 30,96\%; (4) kegiatan konseling kelompok yang dilakukan oleh konselor di TK/SD sebesar 11,21\%, SMP 12,44\% dan SMA 8,77\%; (5) kegiatan pengembangan profesional konselor di TK/SD sebesar 3,36\%, SMP 3,78\%, dan SMA 4,55\%; (6) kegiatan konsultasi oleh konselor di TK/SD sebesar 12,10\%, SMP 13,50\%, dan SMA 11,32\%; (7) kegiatan koordinasi di TK/SD sebesar 5,43\%; SMP 6,38\%; dan SMA 6,11\%; (8) kegiatan administratif di TK/SD sebesar 7,02\%; SMP 11,83\%; dan SMA 17,27\%; dan (9) kegiatan lain yang non-bimbingan di TK/SD sebesar 4,43\%, SMP 5,08\%, dan SMA 3,98\% (Neukrug, 2011).

Kinerja konselor tersebut dapat dipetakan sesuai dengan komponen layanan BK dalam empat layanan (ABKIN, 2007) yaitu: (1) layanan dasar, yang meliputi kegiatan penilaian atau pengujian dan bimbingan; (2) layanan perencanaan individual; (3) layanan responsif, yang meliputi konseling individu, konseling kelompok, konsultasi, dan koordinasi; serta (4) dukungan sistem, yang meliputi pengembangan profesional konselor, kegiatan administratif, dan kegiatan non-bimbingan. Sesuai alokasi waktu yang telah dikemukakan, dapat diketahui bahwa layanan responsif memiliki alokasi waktu yang paling besar (Neukrug, 2011; Studer, Diambra, Breckner, \& Heidel, 2011; Yuksel-Sahin, 2009).

Kinerja konselor dalam menyelenggarakan layanan konseling di sekolah dapat menunjukkan profesionalitas konselor. Banyaknya konselor yang tidak berlatar belakang pendidikan Sarjana BK juga berpengaruh dalam pelaksanaan pemberian layanan (Jumail, 2013). Konselor yang tidak berlatar pendidikan BK kerap mengalami permasalahan dalam penguasaan pengetahuan, sikap, dan teknik dalam melaksanakan konseling. Salah satu dampak dari hambatan ini, siswa enggan untuk berbagi permasalahan mereka kepada konselor. Sebuah temuan menyebutkan bahwa banyak konselor mengeluh terhadap suasana sekolah yang kurang memungkinkan konselor melaksanakan konseling dengan baik (Hambali, 2016). Konselor membutuhkan strategi alternatif layanan individual karena mengalami kesulitan menerapkan pendekatan konseling dalam semua situasi. Konselor juga harus kreatif dalam menerapkan layanan dan strategi konseling untuk memberi layanan kepada siswa dengan baik.

Profesionalitas konselor juga dapat dilihat melalui hubungan kolaborasi dengan guru di sekolah. Konselor sekolah hendaknya berkolaborasi dengan guru untuk mengintegrasikan kurikulum inti konseling, baik pada bidang akademik, pribadi-sosial, dan karier ke dalam kegiatan akademik siswa sehari-hari (Kozlowski, 2013). Hal ini akan meningkatkan prestasi akademik bagi semua siswa dan menutup kesenjangan prestasi. Guru dan konselor memang hendaknya bekerjasama memenuhi kebutuhan sekolah dan siswa (Sherwood, 2010) dan membantu siswa membuat pilihanpilihan karier yang lebih realistis (Munro, 2007). Agar dapat bekerjasama dengan baik, guru mesti punya pemahaman umum tentang tujuan program konseling, peran dan tanggung jawab konselor (Joy, Hesson, \& Harris, 2011). Sementara dalam kerjasama dengan pihak lain, konselor perlu melakukannya untuk mendukung keberhasilan layanan konseling. Pihak lain selaku stakeholder memang mampu menjadi jembatan karier untuk kemajuan performa akademik siswa (Olguin \& Keim, 2009). Konselor hendaknya membuat suatu perencanaan sehingga dapat memanfaatkan pihak lain dalam aktivitas perkembangan karier untuk mendukung kesuksesan akademik siswa.

Selain kurang dalam kolaborasi, di lapangan juga masih banyak dijumpai kinerja konselor sekolah yang lebih condong untuk memenuhi tuntutan formal daripada memenuhi kebutuhan siswa. Konselor merasa sudah bekerja apabila sudah memenuhi tuntutan formal yang berupa tugas-tugas administrasi seperti pengumpulan dan pengisian data dalam berbagai format. Tugas administrasi yang sebenarnya merupakan kegiatan pendukung untuk dapat melakukan layanan dengan baik, dianggap sebagai tugas utama (Sugiharto, 2001).

Kinerja konselor yang profesional dalam menyelenggarakan layanan konseling individual untuk selanjutnya perlu dievaluasi secara objektif. Evaluasi yang objektif, dapat dilihat dari dua segi, yaitu dari diri sendiri dan orang lain yang mengetahui kinerja konselor dalam melaksanakan layanan 
konseling individual. Artikel ini mencoba mengemukakan dan membandingkan hasil evaluasi kinerja konselor dalam menyelenggarakan layanan konseling individual melalui self evaluation dan peer evaluation.

\section{METODE}

\section{Rancangan Penelitian}

Penelitian ini menggunakan metode penelitian kuantitatif. Pendekatan penelitian yang digunakan adalah descriptive survey melalui rancangan descriptive comparative study (Lodico, Spaulding, \& Voegtle, 2010). Penelitian ini akan menggambarkan perbedaan antara kelompok penilaian kinerja konselor dalam menyelenggarakan layanan konseling individual di sekolah melalui instrumen self evaluation dan peer evaluation berdasarkan lamanya bekerja sebagai konselor dan latar belakang pendidikan.

\section{Subjek Penelitian}

Subjek penelitian adalah konselor sekolah di Kabupaten Bantul Daerah Istimewa Yogyakarta yang dipilih menggunakan teknik purposive sampling (Leedy \& Ormrod, 2005). Peneliti memilih semua konselor yang tergabung dalam Musyawarah Guru BK (MGBK) di Kabupaten Bantul Daerah Istimewa Yogyakarta, yaitu sejumlah 30 orang konselor.

\section{Instrumen Penelitian}

Penelitian ini menggunakan instrumen inventori berupa self evaluation dan peer evaluation kinerja konselor dalam menyelenggarakan layanan konseling individual di sekolah (Barida \& Sutarno, 2016). Instrumen ini telah dikembangkan melalui serangkaian proses penelitian dengan model penelitian Research and Development (R\&D) sampai tahap kesembilan (Borg \& Gall, 1971). Instrumen berisi 50 butir pernyataan tentang self evaluation dan 50 butir pernyataan tentang peer evaluation untuk mengetahui kinerja konselor dalam menyelenggarakan layanan konseling individual di sekolah.

\section{Pengumpulan Data}

Data dikumpulkan dengan instrumen inventori self evaluation dan peer evaluation kinerja konselor dalam menyelenggarakan layanan konseling individual di sekolah. Peneliti menggunakan serangkaian pernyataan verbal yang menunjukkan aspek-aspek kinerja konselor dalam menyelenggarakan layanan konseling individual di sekolah. Skala jawaban berupa data numerik untuk dipilih oleh subjek.

\section{Analisis Data}

Hasil pengumpulan data dianalisis menggunakan teknik analisis statistik Non-parametric Mann Whitney U, karena: (1) sesuai hasil uji normalitas Shapiro Wilk, $p$ value uji Shapiro Wilk pada self evaluation sebesar $0,029<0,05$ dikatakan tidak berditribusi normal dan pada peer evaluation sebesar 0,222 >0,05 dikatakan berdistribusi normal; dan (2) berdasarkan hasil uji homogenitas Levene Statistic, diketahui nilai self evaluation tidak homogen. Peneliti membandingkan rata-rata nilai kinerja konselor dalam menyelenggarakan layanan konseling individual di sekolah melalui instrumen self evaluation dan peer evaluation. Apabila nilai probabilitas atau signifikansi di atas $0,05(\mathrm{p}>0,05)$ maka hipotesis nul $\left(\mathrm{H}_{\mathrm{o}}\right)$ diterima, dan apabila nilai probabilitas atau signifikansi di bawah $0,05(\mathrm{p}<0,05)$ maka hipotesis nul $\left(\mathrm{H}_{\mathrm{o}}\right)$ ditolak. Peneliti menggunakan bantuan program SPSS 21.0 for Windows untuk melakukan analisis dengan teknik analisis ini. 


\section{HASIL}

Hasil pengisian instrument self evaluation dan peer evaluation diuraikan pada tabel 1 . Hipotesis yang diajukan yaitu ada perbedaan antara self evaluation dan peer evaluation $\left(\mathrm{H}_{\mathrm{a}}\right)$. Apabila nilai signifikansi atau probabilitas kurang dari $0,05(<0,05)$ maka $\mathrm{H}_{\mathrm{a}}$ diterima. Sebaliknya, apabila nilai signifikansi atau probabilitas lebih dari $0,05(>0,05)$ maka $\mathrm{H}_{\mathrm{a}}$ ditolak.

Peneliti menggunakan Mann-Whitney U melalui program bantuan SPSS 21.0 for Windows untuk menguji perbedaan kinerja konselor dalam menyelenggarakan layanan konseling di sekolah sesuai self evaluation dan peer evaluation. Hasil rata-rata self evaluation dan peer evaluation disajikan pada tabel 2. Tabel 2 menunjukkan rata-rata peringkat tiap kelompok sumber data. Pada kelompok self evaluation rerata peringkatnya 29,50 lebih rendah dari pada rerata peringkat peer evaluation, yaitu 31,50 .

Tabel 1 Hasil Pengisian Instrumen

\begin{tabular}{|c|c|c|c|}
\hline No & Inisial Subjek & Jumlah Skor Self Evaluation & Jumlah Skor Peer Evaluation \\
\hline 1 & W & 130 & 130 \\
\hline 2 & IS & 133 & 104 \\
\hline 3 & $\mathrm{SN}$ & 106 & 124 \\
\hline 4 & SM & 107 & 123 \\
\hline 5 & PM & 104 & 121 \\
\hline 6 & AA & 108 & 117 \\
\hline 7 & SA & 137 & 120 \\
\hline 8 & SU & 129 & 130 \\
\hline 9 & SrA & 133 & 139 \\
\hline 10 & $\mathrm{H}$ & 137 & 139 \\
\hline 11 & JW & 144 & 141 \\
\hline 12 & B & 143 & 138 \\
\hline 13 & $\mathrm{Sa}$ & 133 & 118 \\
\hline 14 & LS & 126 & 133 \\
\hline 15 & $\mathrm{Si}$ & 113 & 122 \\
\hline 16 & IS & 129 & 135 \\
\hline 17 & St & 133 & 128 \\
\hline 18 & SR & 131 & 133 \\
\hline 19 & $\mathrm{Gi}$ & 111 & 111 \\
\hline 20 & SH & 113 & 110 \\
\hline 21 & BY & 140 & 137 \\
\hline 22 & $\mathrm{R}$ & 125 & 136 \\
\hline 23 & SW & 140 & 123 \\
\hline 24 & RK & 125 & 141 \\
\hline 25 & $\mathrm{Ri}$ & 133 & 139 \\
\hline 26 & $\mathrm{Sd}$ & 137 & 145 \\
\hline 27 & SS & 117 & 118 \\
\hline 28 & DS & 122 & 140 \\
\hline 29 & SZ & 139 & 129 \\
\hline 30 & $\mathrm{TS}$ & 112 & 116 \\
\hline
\end{tabular}


Tabel 2 Hasil Rata-rata Self Evaluation dan Peer Evaluation

\begin{tabular}{lllll}
\hline Kelompok & & N & Mean Rank & Sum of Ranks \\
\hline Nilai & Self Evaluation & 30 & 29,50 & 885,00 \\
& Peer Evaluation & 30 & 31,50 & 945,00 \\
& Total & 60 & & \\
\hline
\end{tabular}

Tabel 3 Hasil Mann-Whitney U Self Evaluation dan Peer Evaluation

\begin{tabular}{ll}
\hline & Nilai \\
\hline Mann-Whitney U & 420,000 \\
Wilcoxon W & 885,000 \\
Z &,- 444 \\
Asymp. Sig. (2-tailed) &, 657 \\
\hline
\end{tabular}

Tabel 3 menunjukkan nilai U sebesar 420 dan nilai W sebesar 885. Apabila dikonversikan ke nilai $\mathrm{Z}$ maka besarnya $-0,444$. Nilai Sig atau $p$ value sebesar $0,657>0,05$. Diketahui bahwa tidak ada perbedaan yang signifikan kinerja konselor dalam layanan konseling individual berdasarkan self evaluation dan peer evaluation.

\section{PEMBAHASAN}

Evaluasi kinerja konselor terdiri dari aspek: (1) perencanaan layanan konseling individual; (2) pelaksanaan layanan konseling individual; dan (3) evaluasi layanan konseling individual. Perencanaan layanan konseling individual terdiri dari menganalisis kebutuhan siswa terhadap layanan konseling dan menyusun rencana layanan konseling yang berkelanjutan berdasar kebutuhan siswa secara komprehensif dengan pendekatan perkembangan. Pelaksanaan layanan konseling individual, terdiri dari: (a) melaksanakan rencana layanan konseling; (b) menggunakan pendekatan kolaboratif dalam layanan konseling; (c) memfasilitasi perkembangan pribadi, sosial, akademik, dan karier siswa melalui layanan konseling; dan (d) mengelola sarana dalam melaksanakan layanan konseling. Evaluasi layanan konseling individual terdiri dari melakukan evaluasi proses layanan konseling dan melakukan evaluasi hasil layanan konseling. Evaluasi dapat dilakukan oleh diri sendiri (self evaluation) dan orang lain yang mengetahui kinerja konselor dalam menyelenggarakan layanan konseling individual (peer evaluation).

Hasil penelitian menunjukkan bahwa self evaluation dan peer evaluation kinerja konselor dalam menyelenggarakan layanan konseling individual menunjukkan hasil yang relevan. Evaluasi ini sangat berguna sebagai pendataan yang akuntabel sehingga dapat dimanfaatkan dalam perbaikan kinerja konselor. Konselor sebagai bagian dari sistem pendidikan di sekolah harus melakukan perbaikan dalam melaksanakan layanan bimbingan dan konseling (Shaterloo \& Mohammadyari, 2011). Sebuah studi menunjukkan bahwa evaluasi kinerja dalam bidang pendidikan berguna dalam pengetahuan, pemahaman, dan pelaksanaan mekanisme pengajaran dan pembelajaran kunci, khususnya di bidang perencanaan, pengajaran, penilaian, dan refleksi pendidik (Brown, Suh, Parsons, Parker, \& Ramirez, 2015). Melalui evaluasi kinerja ini, konselor dapat memperbaiki perencanaan, pelaksanaan, maupun evaluasi layanan konseling individual di sekolah.

Hasil studi lain menyimpulkan bahwa pendidik merasakan manfaat potensial dari kegiatan evaluasi, mereka dapat menyadari adanya hambatan yang ada pada pengimplementasian program (Spina, Buckley, \& Puchner, 2014). Kegiatan evaluasi juga memberikan strategi yang menguntungkan bagi pemerintah. Hasil evaluasi dapat dijadikan pemerintah acuan untuk melakukan transisi menuju model baru evaluasi kinerja pendidik yang efektif. Hal ini juga dapat dijadikan acuan untuk meningkatkan kinerja konselor dan pengembangan sistem evaluasi konselor yang lebih efektif. 
Evaluasi kinerja dapat dilaksanakan secara akuntabel dengan mengevaluasi bukti praktik, bukti hasil, dan umpan balik (Clifford, 2015). Dalam kegiatan tersebut, bukti praktik digunakan untuk menilai kualitas kinerja konselor dan bukti hasil menentukan sejauh mana kinerja konselor dikaitkan dengan hasil kontribusi terhadap sekolah, seperti peningkatan budaya sekolah atau pencapaian perkembangan siswa. Umpan balik mencakup percakapan antara konselor dengan pihak lain yang memberikan umpan balik, dalam hal ini adalah rekan konselor. Secara keseluruhan, komponen tersebut memberikan gambaran kinerja secara menyeluruh dan memetakan jalan untuk refleksi dan perkembangan.

Proses pemberian umpan balik atas kinerja konselor merupakan salah satu kesempatan untuk melibatkan murid dalam pelaksanaan evaluasi kinerja konselor. Sistem evaluasi sulit dikembangkan dan dimanfaatkan secara efektif, namun ketika melibatkan siswa, balikan mereka akan sangat membantu pengembangan profesi (Warring, 2015). Adanya siswa dan rekan kerja konselor yang lebih dekat dengan konselor yang dievaluasi, dapat memberikan kontribusi dalam jangka waktu yang lebih panjang daripada sekedar penilaian formalitas yang biasanya dilakukan oleh Dinas Pendidikan. Pelaksanaan evaluasi pengajaran ternyata juga dapat memengaruhi guru untuk memberikan nilai yang lebih baik pada siswa (Chen, Wang, \& Yang, 2017), jika dikaitkan dengan layanan BK, pelaksanaan evaluasi kinerja konselor, akan berdampak pemberian layanan konselor yang lebih baik.

Adanya evaluasi yang sifatnya eksternal dan ditindaklanjuti secara internal, secara tidak langsung dapat membawa perubahan peningkatan kinerja konselor dalam melaksanakan layanan konseling. Evaluasi eksternal dapat membantu memperkuat program konseling sekolah dan meningkatkan legitimasi BK dalam sistem sekolah (Martin \& Rallis, 2014). Evaluasi sekolah merupakan alat yang relevan dan pragmatis untuk lebih mendukung kekuatan evaluasi program internal yang telah ada di sekolah-sekolah melalui strategi evaluasi program eksternal.

Evaluasi terhadap kinerja konselor dalam layanan konseling individual perlu dilakukan secara berkelanjutan. Peer evaluation yang melibatkan rekan kerja konselor yang bertugas mengamati dan menilai praktik layanan dapat digunakan sebagai masukan dalam menentukan penilaian akhir evaluasi. Jika suatu sekolah perlu mengadakan evaluasi internal, maka diperlukan tiga pengamatan praktik konselor. Ketiga pengamatan tersebut dapat dilakukan oleh satu atau dua rekan sesama konselor dan seorang atasan (kepala sekolah). Pengamat akan menggunakan hasil pengamatan masing-masing untuk menentukan nilai praktik, atau penilaian masing-masing pengamatan akan digabungkan (misalnya dengan rata-rata) untuk menghasilkan penilaian praktik akhir. Peer evaluation dapat menjadi bagian dari program peer assistance and review, yang biasanya berfokus pada guru baru atau yang berjuang dan memberikan suatu rekomendasi evaluator kepada rekan evaluator apakah guru tersebut diteruskan atau diberhentikan (Milanowski, Heneman III, \& Finster, 2015).

\section{SIMPULAN}

Dari hasil penelitian dapat disimpulkan bahwa tidak ada perbedaan penlaian kinerja konselor dalam menyelenggarakan layanan konseling individual di sekolah melalui pengisian instrumen inventori self evaluation oleh diri konselor sendiri dan peer evaluation oleh rekan konselor di sekolah. Kinerja konselor perlu dievaluasi dengan prinsip relasi kolegial, sehingga konselor merasa tidak terintimidasi dan lebih bersemangat untuk meningkatkan kinerja.

\section{DAFTAR RUJUKAN}

Asosiasi Bimbingan dan Konseling Indonesia. (2007). Penataan Pendidikan Profesional Konselor dan Layanan Bimbingan dan Konseling dalam Jalur Pendidikan Formal (Naskah Akademik), Bandung: ABKIN.

Barida, M., \& Sutarno, S. (2016). Pengembangan Instrumen Evaluasi "Self Evaluation" dan "Peer Evaluation" Layanan Konseling Individual di Sekolah bagi Konselor. Jurnal Konseling dan Pendidikan, 4(2), 110-117. https://doi.org/10.29210/17200 
Borg, W. R., \& Gall, M. D. (1971). Educational Research: An Introduction. McKay.

Brown, E. L., Suh, J., Parsons, S. A., Parker, A. K., \& Ramirez, E. M. (2015). Documenting Teacher Candidates' Professional Growth through Performance Evaluation. Journal of Research in Education, 25(1), 35-47.

Chen, C. Y., Wang, S.-Y., \& Yang, Y.-F. (2017). A Study of the Correlation of The Improvement of Teaching Evaluation Scores Based on Student Performance Grades. International Journal of Higher Education, 6(2), 162-168.

Clifford, M. (2015). Building Leadership Talent through Performance Evaluation. American Institutes for Research.

Hambali, I. (2016). Model Dialog "4D" untuk Meningkatkan Kesadaran Multi Kultural Siswa SMA di Kota Malang. Jurnal Kajian Bimbingan dan Konseling, 1(3), 95-103. https://doi. org/10.17977/um001v1i32016p095

Joy, R. M., Hesson, J. B., \& Harris, G. E. (2011). Preservice Teacher Perceptions of School Counsellor Responsibilities/Perceptions des responsabilités du conseiller scolaire chez les professeurs futurs. Canadian Journal of Counselling and Psychotherapy, 45(4), 386-405.

Jumail, J. (2013). Kompetensi Profesional dalam Perspektif Konselor Sekolah dan Peranannya terhadap Pelayanan Bimbingan dan Konseling di SMA Negeri Se-Kota Padang. KONSELOR, 2(1), 250-255.

Kozlowski, K. A. (2013). Integrating School Counseling Core Curriculum Into Academic Curriculum. Journal of School Counseling, 11(5), 1-35.

Leedy, P. D., \& Ormrod, J. E. (2005). Practical Research. Pearson Custom.

Lodico, M. G., Spaulding, D. T., \& Voegtle, K. H. (2010). Methods in Educational Research: From Theory to Practice (Vol. 28). John Wiley \& Sons.

Martin, I., \& Rallis, S. (2014). Building on Strengths and Addressing Challenges: Enhancing External School Counseling Program Evaluation. Journal of School Counseling, 12(10), 1-29.

Milanowski, A., Heneman III, H. G., \& Finster, M. (2015). Peer Evaluation of Teachers in Maricopa County's Teacher Incentive Fund Program. Teacher Incentive Fund, US Department of Education.

Munro, H. (2007). The Implications of Teacher Perceptions of Career Guidance Programs and The Impact on Student Career Decisions. Georgia School Counselors Association Journal, 14, 6-13.

Neukrug, E. (2011). The World of the Counselor: An Introduction to the Counseling Profession. Nelson Education.

Nurse, A. M. (2014). Setting the Bar High: Danish Youth Education Counselors and National SchoolCompletion Goals. International Journal for The Advancement of Counselling, 36(3), 287-304. https://doi.org/10.1007/s10447-014-9207-2

Olguin, D. L., \& Keim, J. (2009). Using Stakeholders as Career Bridges to Advance Students' Academic Performance: How Would You Like Your Stake? Journal of School Counseling, $7(22), 1-22$.

Radjah, C. L. (2016). Keterampilan Konseling Berbasis Metakognisi. Jurnal Kajian Bimbingan dan Konseling, 1(3), 90-94. https://doi.org/10.17977/um001v1i32016p090

Shaterloo, A., \& Mohammadyari, G. (2011). Students Counselling and Academic Achievement. Procedia - Social and Behavioral Sciences, 30, 625-628. https://doi.org/10.1016/j. sbspro.2011.10.121

Sherwood, H. (2010). Utilizing Staff Perceptions to Guide and Shape Future Program Planning. Georgia School Counselors Association Journal, 17(1), 15-25. 
Spina, N., Buckley, P., \& Puchner, L. (2014). Shifting Practices in Teacher Performance Evaluation: A Qualitative Examination of Administrator Change Readiness. Education Leadership Review of Doctoral Research, 1(2), 113-128.

Studer, J. R., Diambra, J. F., Breckner, J. A., \& Heidel, R. E. (2011). Obstacles and Successes in Implementing the ASCA National Model in Schools. Journal of School Counseling, 9(2), 1-26.

Sugiharto, D. Y. P. (2001). Peran dan Kinerja Pembimbing dalam Peningkatan Mutu Layanan Bimbingan dan Konseling.

Warring, D. F. (2015). Teacher Evaluations: Use or Misuse?. Universal Journal of Educational Research, 3(10), 703-709.

Yuksel-Sahin, F. (2009). The Evaluation of Counseling and Guidance Services Based on Teacher Views and Their Prediction Based on Some Variables. International Journal of Instruction, 2(1), 59-76. 